\title{
Maximum Power Point Tracking in Solar and Wind Hybrid Energy Conversion System
}

\author{
K. Ishwarya ${ }^{1} \mid$ Dr. K. Yasoda ${ }^{2}$
}

${ }^{1} \mathrm{PG}$ Scholar, Department of EEE, Government College of Technology, Coimbatore, Tamilnadu, India.

${ }^{2}$ Assistant Professor, Department of EEE, Government College of Technology, Coimbatore, Tamilnadu, India.

To Cite this Article

K. Ishwarya, Dr. K. Yasoda, "Maximum Power Point Tracking in Solar and Wind Hybrid Energy Conversion System", International Journal for Modern Trends in Science and Technology, Vol. 06, Issue 07, July 2020, pp.:159-164; https://doi.org/10.46501/IJMTST060726

Article Info

Received on 12-June-2020, Revised on 30-June-2020, Accepted on 18-July-2020, Published on 24-July-2020.

\section{ABSTRACT}

In this paper, Maximum power point is tracked in both solar and wind energy conversion system using MPPT controller and also analyzed the performance of the renewable energy system with MPPT and without MPPT controller. Among all the renewable resources, Solar and Wind are the most popular resources due to its ease of availability. Alone PV system or Wind system cannot completely meet load demands.Hence photovoltaic and wind system are hybridized and optimized to satisfy the load demand. This paper proposed a standalone hybrid renewable energy system which employs incremental conductance algorithm for photovoltaic system and perturb and observe algorithm for wind energy conversion system is implemented. Usage of this system combines the advantages of each generation system and provides electrical power to meet various load conditions. Maximization and stabilization of power from the system with and without MPPT controller is designed and analyzed in MATLAB/Simulink environment.

KEYWORDS: Hybrid renewable energy system, MPPT controller, PV system, Wind system

Copyright (C) 2020 International Journal for Modern Trends in Science and Technology

DOI: https://doi.org/10.46501/IJMTST060726

\section{INTRODUCTION}

Now a days the requirement of electrical power generation is increased rapidly by satisfying the load demand. In recent years use of renewable energy resources are gaining more attention due to the depletion of existing fossil fuels like coal, gas. The fossil fuels pollute environment in many field and also its rapid augmentation of the prices. Renewable sources like wind, solar, hydro and biomass have the substantial capabilities to compensate for the increasing energy demands. In other side renewable energy resources presents a real investment. Among these renewable sources solar and wind energy are the world's fastest growing energy resources. With no emission of pollutants, energy conversion is done through wind and PV cells. The power generation from the PV system depends on the availability of solar irradiation and wind system depends on the wind velocity respectively. Alone PV system and wind system cannot completely meet load demand, advantages of each system is combined to form a hybrid renewable energy system. By using this system the load demands are satisfied. Fig. 1 shows the block diagram of the hybrid renewable energy system. The basic block diagram of hybrid renewable energy system consists of PV source, wind source, DC-DC boost converter, MPPT controller, inverter, DC load and an AC load. In PV source and wind source the current and voltage signals are obtained by voltage and current 
measurement. These voltage and current values are input to the MPPT controller. Then MPPT can track the maximum power point by its algorithm. The output of MPPT controller is given to PWM generator that generator gives gate pulse to DC-DC boost converter. The boost converter maintaining the operating voltage at the maximum power point as function of variation of its duty cycle.

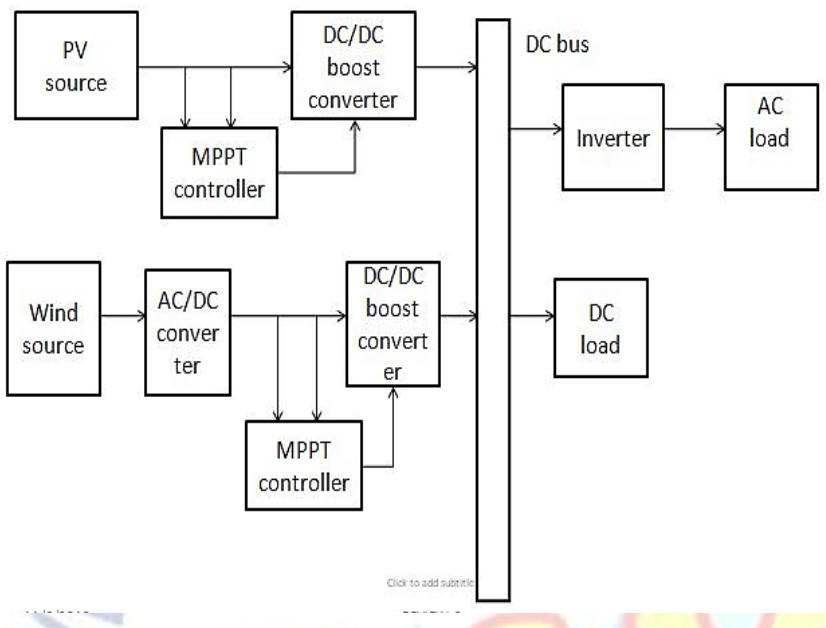

Fig.1 Block diagram of hybrid renewable energy system

There are several MPPT technique in the literature like Perturb and Observe( $\mathrm{P} \& \mathrm{O})$, Incremental Conductance (IC), Hill Climbing (HC) and Constant Voltage Tracking (CVT). Most popular MPPT technique for solar and wind energy system are Perturb and Observe (P\&O), Incremental Conductance (IC) method because of its simplicity and easy implementation. The MPPT system calculates the maximum available power in the PV and wind generation system, and then compares the calculated power with the actual drawn power for generating the switching signals of the DC-DC boost converter of the MPPT system.

\section{DESIGN OF HYBRID ENERGY SYSTEM}

\section{Solar energy system}

The photovoltaic system converts sunlight directly to electricity without having any disastrous effect on our environment. The basic segment of PV array is PV cell, which is just a simple $\mathrm{P}-\mathrm{N}$ junction device. The fig. 2 shows the equivalent circuit of PV cell. The equivalent circuit has a current sources, a diode parallel to it, $R_{S}$ represents series resistance and $R_{S h}$ represents shunt resistance which is inversely in relation with leakage current to the ground. Series resistor has great impact on the I-V characteristic of solar cell.

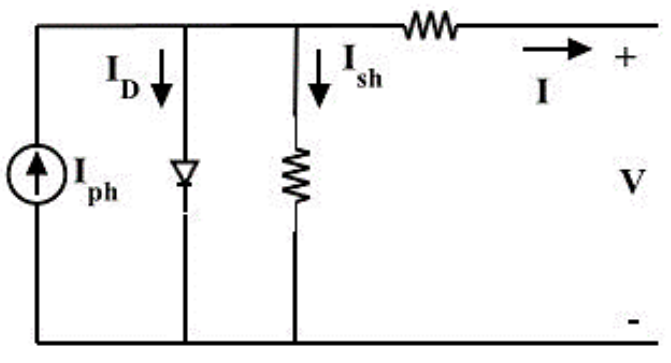

Fig.2 Equivalent circuit of solar cell

The term $I_{D}$ represents diode current and $I_{s h}$ represents shunt leakage current. The current supplied to the load can be given as

$$
\mathrm{I}=\mathrm{I}_{\mathrm{pV}}-\mathrm{I}_{0}\left[\exp \left(\frac{N+\mathrm{IR}_{\mathrm{S}}}{\mathrm{aV} V_{\mathrm{T}}}\right)-1\right]-\left(\frac{V+\mathrm{IR}_{\mathrm{S}}}{\mathrm{R}_{\mathrm{p}}}\right)
$$

Where

$\mathrm{I}_{\mathrm{PV}}$ - Photovoltaic current

$I_{0}$ - Diode's reverse saturation current

$V$ - Voltage across the diode

a- Ideality factor

$\mathrm{V}_{\mathrm{T}}$ - Thermal voltage

$\mathrm{R}_{\mathrm{S}}$ - Series resistance

$\mathrm{R}_{\mathrm{p}}-$ Shunt resistance

PV cell photocurrent, which depends on the radiation and temperature, can be expressed as,

$$
\mathrm{I}_{\mathrm{PV}=\left(\mathrm{I}_{\mathrm{PV}-\mathrm{sTC}}+\mathrm{K}_{\mathrm{L}} \Delta \mathrm{T}\right)} \frac{\mathrm{G}}{\mathrm{G}_{\mathrm{STC}}}
$$

\section{Where}

$\mathrm{K}_{\mathrm{I}}-$ Cell's short circuit current temperature coefficient

G- Solar irradiation in $\mathrm{W} / \mathrm{m}^{2}$

$\mathrm{G}_{\text {STC }}$ - Nominal solar irradiation in $\mathrm{W} / \mathrm{m}^{2}$

$\mathrm{I}_{\mathrm{PV}-\mathrm{STC}}$ - Light generated current under standard test condition

The reverse saturation current varies as a cubic function of temperature, which is represented as

$I_{0}=\frac{\left(U_{S C-S T C}+K_{I} \Delta T\right)}{\exp \left[\frac{\left(V_{O C-S T C}+K_{V} \Delta T\right)}{a V_{T}}\right]-1}$

Where

$I_{S C-S T C}-$ Short circuit current at standard test condition

$V_{O C-S T C}-$ Short circuit voltage at standard test condition

$K_{V}$ - Temperature coefficient of open circuit voltage 


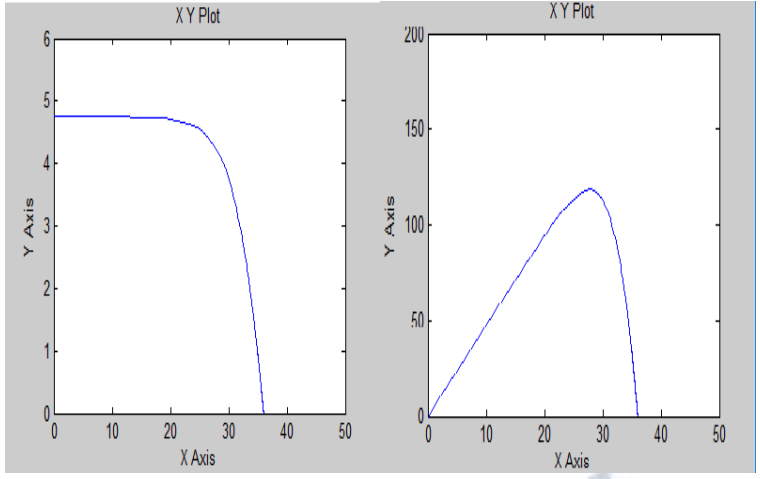

Fig.3 I-V and P-V Characteristics of PV cell

The fig-3 shows the I-V and P-V characteristics of the PV module. From the figure the short circuit current of PV module is approximately 4.75A and open circuit voltage is approximately $36 \mathrm{~V}$ and also the maximum power is approximately $130 \mathrm{~W}$.

\section{Wind energy conversion system}

The modelling of wind energy system depends on modeling of wind turbine and wind generator. Here permanent magnet synchronous generator is used as a wind generator. The equation for the power generated is shown below.

$$
P_{M}=\frac{1}{2} \pi \rho C_{p}\left(\lambda_{s} \beta\right) R^{2} V^{a}
$$

Where

$P_{M}$ - Power captured by wind turbine

$\rho-$ Air density

$\square$ - Pitch angle (in degrees)

$V$ - Blade radius (in degrees)

$V$ - Wind speed (in $\mathrm{m} / \mathrm{s}$ )

The term $\lambda$ is the tip-speed ratio, given by the equation

$\lambda=\frac{\Omega R}{V}$

Where

$\Omega$ - Rotor speed of rotation (in $\mathrm{rad} / \mathrm{sec}$ )

$\mathrm{R}$ - Resistance

$\mathrm{V}$ - Voltage

$\mathrm{C}_{\mathrm{P}}$ can be expressed as the function of the tip-speed ratio $(\lambda)$

$C_{P}=\frac{1}{2}\left(\frac{116}{\lambda 1}-0.4 \beta-5\right) \exp ^{\frac{-165}{\lambda 1}}$ $\lambda 1=\left(\frac{1}{\frac{1}{\lambda+0.089}-\frac{0.035}{\beta^{2}+1}}\right)$

Where

$\mathrm{C}_{\mathrm{P}}-$ Wind turbine power coefficient

$\lambda$ - Tip-speed ratio

$\lambda 1$ - Constant

\section{DC-DC Boost converter}

Boost converter is also known as step up converter, where the output voltage is higher than the input. The current carried by the inductor starts rising and it stores energy during ON time of the switching element. The circuit is said to be in charging state. During OFF condition, the reverse energy of the inductor starts dissipating into the load along with the supply. The output voltage level exceeds that of the input voltage and is dependent on the inductor time constant. The load side voltage is the ratio of source side voltage and the duty ratio of the switching device. The boost converter parameters are given by the following.

$\frac{V_{0}}{V_{I N}}=\frac{I_{I U}}{I_{O}}=\frac{1}{1-D}$

Where

D - Duty cycle

$V_{I N}$ - Input voltage

$I_{0}-$ Output current

$$
\begin{gathered}
\text { Inductance }(L)=\frac{V_{\text {out }} D}{\Delta i f} \\
\text { Capacitor }(C)=\frac{D}{R\left(\Delta V_{\text {out }} / V_{\text {out }}\right) f}
\end{gathered}
$$

Where

$V_{\text {out }}$ - Output voltage

$\Delta V_{\text {out }}$ - Ripple voltage

$\Delta i$ - Ripple current

$f$ - Switching frequency

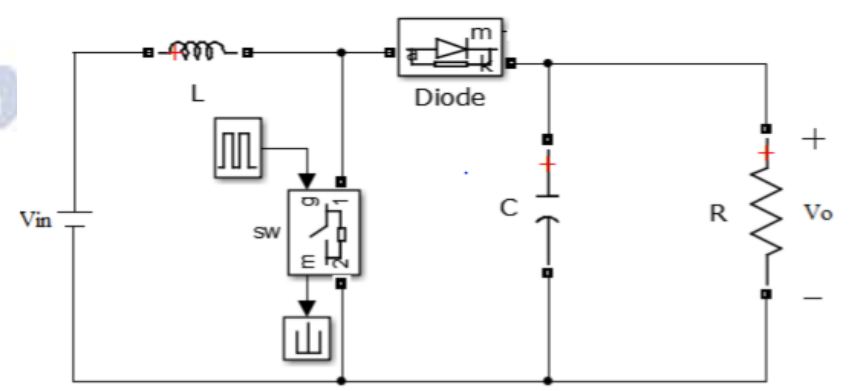

Fig.4Modelling of boost converter 
Fig. 4 shows the mathematical modelling of boost converter, boost converter used to boost the system voltage for getting the maximum output power.

\section{MPPT CONTROLLER}

Maximum power point tracking is a technique used commonly with wind turbines and photovoltaic system to maximize power extraction under all conditions. Several MPPT algorithms are available, the most popular tracking algorithms are Perturb and Observe (P\&O), Incremental conductance methods(IC) and Hill climbing (HC).

\section{Incremental conductance algorithm}

In the incremental conductance method, the controller measures incremental changes in PV array current and voltage to predict the effect of a voltage change. The flowchart of the Incremental Conductance (IC) MPPT technique is shown in the fig. 5 .

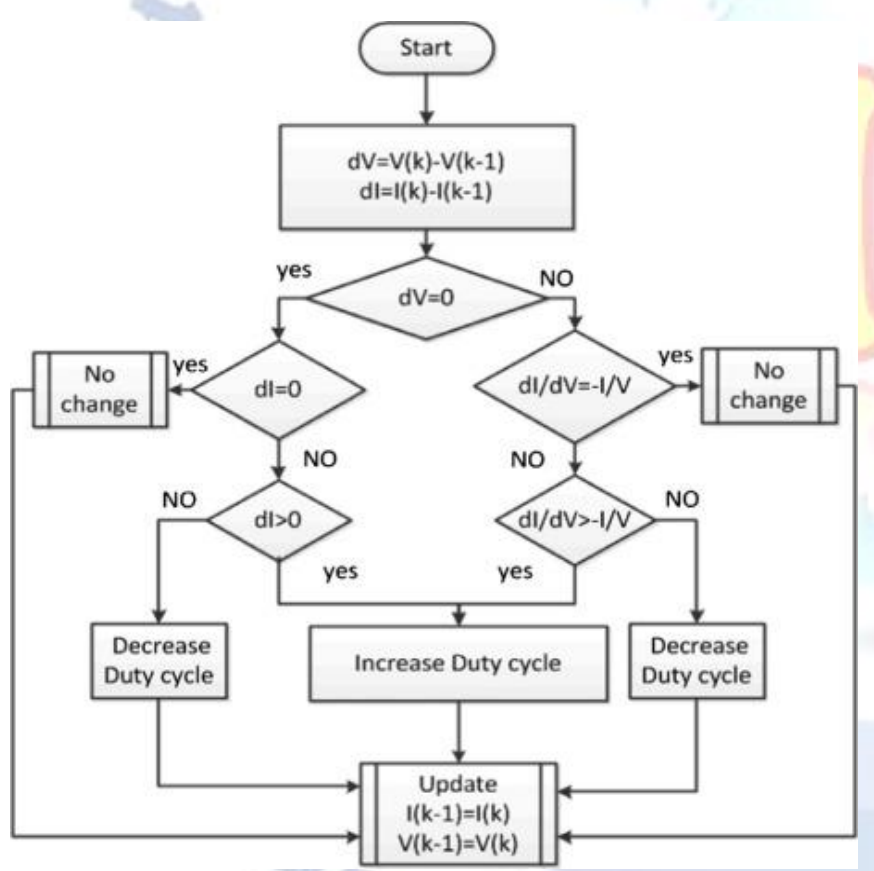

Fig.5 Flow chart of Incremental Conductance MPPT technique

In this method calculates the $\mathrm{dV}$ and $\mathrm{dI}$ by measuring the PV panel current $I(K)$ and $V(K)$. The incremental conductance method computes the maximum power point by comparison of the incremental conductance $(d l / d V)$ to the array conductance $(\mathrm{I} / \mathrm{V})$. When these two are the same $(\mathrm{I} / \mathrm{V}=\mathrm{dI} / \mathrm{dV})$ the output voltage is the maximum power point voltage. The controller maintains this voltage until the irradiation changes and the process is repeated.

\section{Perturb and observe algorithm}

Perturb and Observe is the most commonly used MPPT method due to its ease of implementation. In this method the maximum power point tracked by comparing the recent power is compared with previous power. The flowchart of Perturb and Observe MPPT techniques is shown in fig.6.

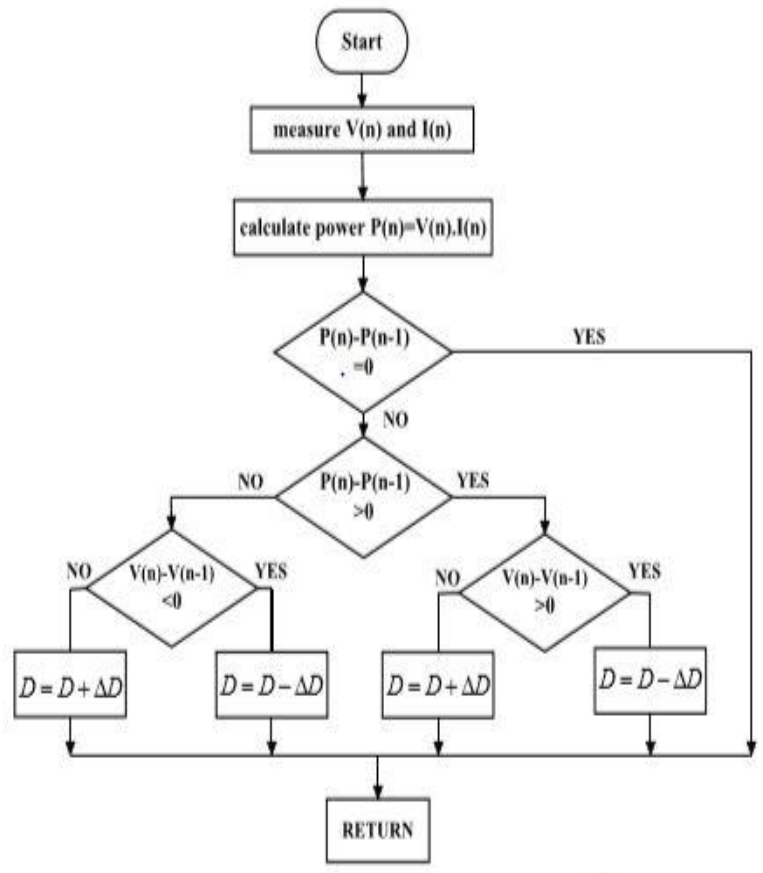

Fig.6 Flowchart of Perturb and Observe MPPT technique

The perturb and observe MPPT technique algorithm calculates the power $\mathrm{P}(\mathrm{n})$ by measuring the voltage $\mathrm{V}(\mathrm{n})$ and current $\mathrm{I}(\mathrm{n})$ and then compares it with last calculated power $P(n-1)$. If the output power increases, the next duty cycle change keeps the same direction, otherwise the dutycycle changes in the opposite direction. The duty cycle of the DC-DC converter is varied till it reaches the maximum power point.

\section{RESULTS AND DISCUSSION}

In order to analyze performance of the hybrid renewable energy conversion system with MPPT controller technique and without MPPT controller technique are simulated in MATLAB/Simulink environment. The results are obtained and discussed in given below. The output waveform of voltage, current and power with respect to time for a solar system without maximum power point tracking represented in fig- 7 . The solar system has specification the maximum voltage is $36 \mathrm{~V}$ and the maximum current value is $4.75 \mathrm{~A}$. 


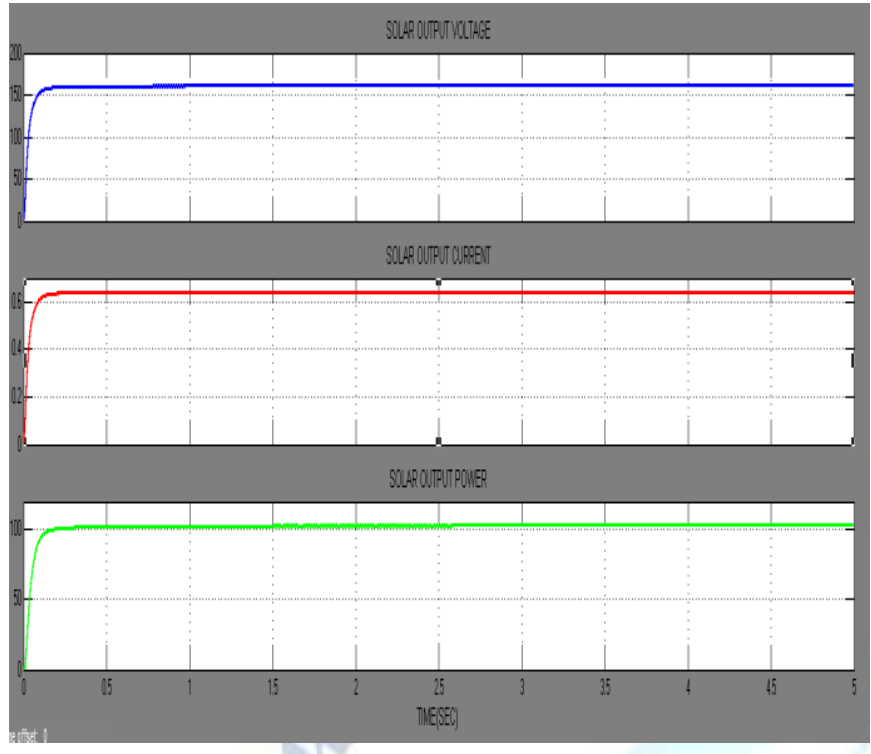

Fig.7 Output waveform of PV system without MPPT controller

The fig. 8 shows the output waveform of PV system with MPPT controller that shows the output voltage, current and power respectively. In Photovoltaic system the maximum power was tracked by using the incremental conductance algorithm.

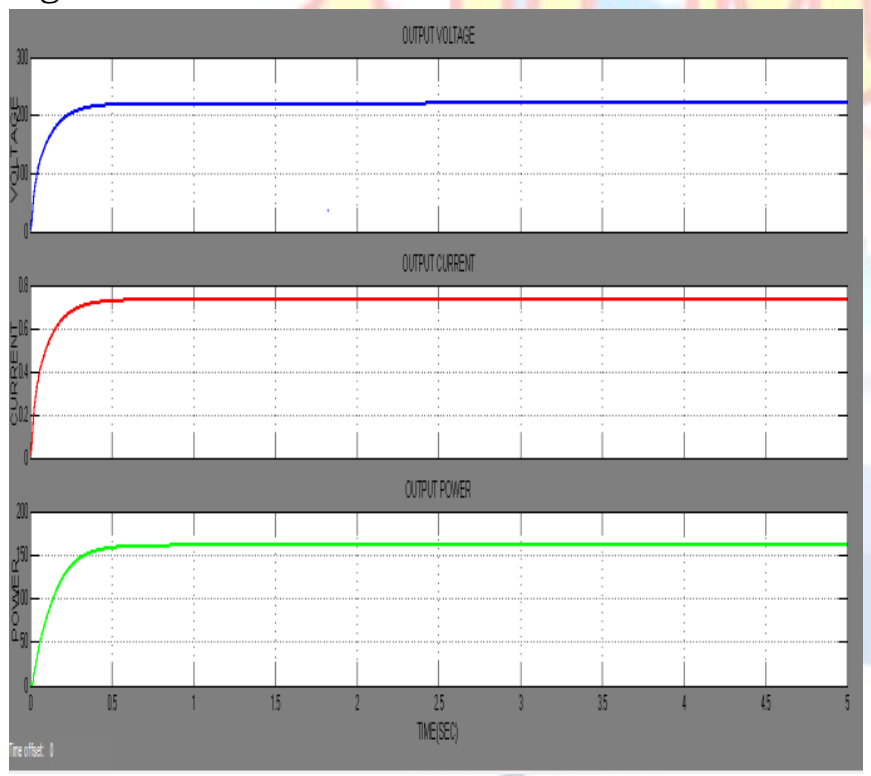

Fig.8 Output waveform of Wind system without MPPT controller

Fig.9 represented the output waveform of the wind energy conversion system without maximum power point controller. The output waveform shows the voltage, current and power with respect to time. The Perturb and observe MPPT algorithm was used to track the maximum power in the wind energy conversion system.

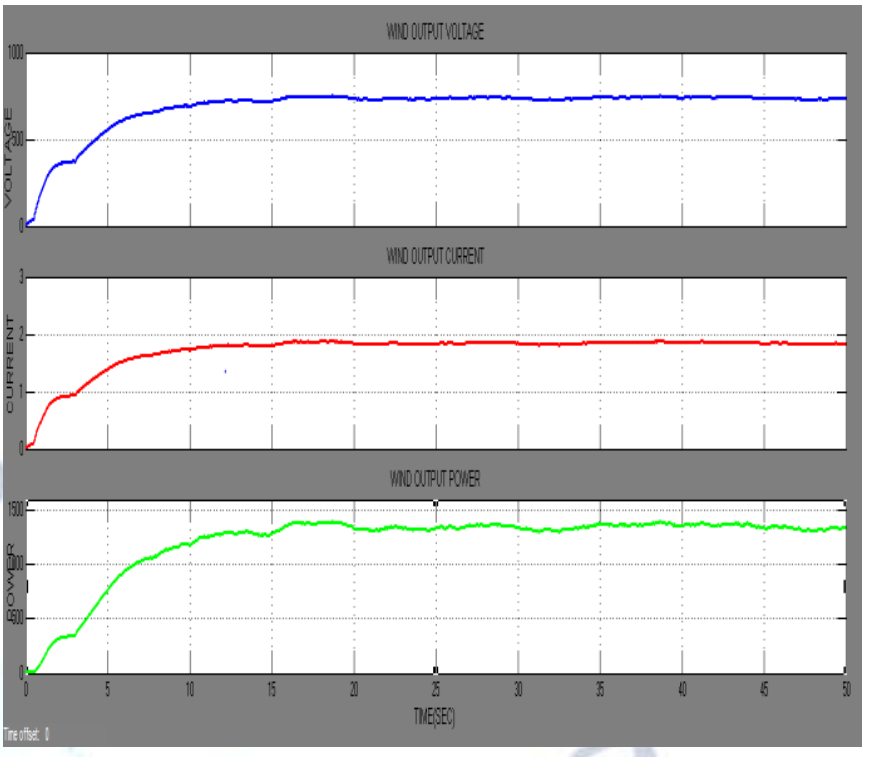

Fig.9 Output waveform of Wind system without MPPT controller

Fig.10 shows the output waveforms of wind energy conversion system with MPPT controller. That are output voltage, current and power respectively.

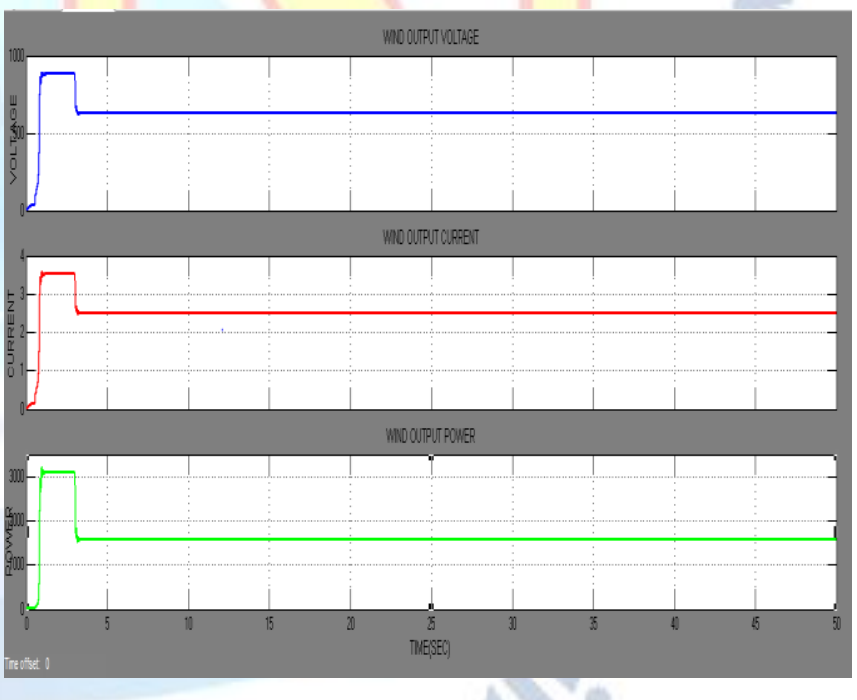

Fig.10 Output waveform of Wind system with MPPT controller

Table 1 shows the comparative analysis of Photovoltaic system and wind energy conversion system. The comparisonis about with MPPT controller and without MPPT controller in both the energy systems. The corresponding values of the systems are mentioned in the table. From the comparison, we observed that, in the present of MPPT controller can produce maximum power in both the renewable energy systems, when compare to the without MPPT controller. 
Table 1 Comparative Analysis of PV and Wind system

\begin{tabular}{|c|c|c|c|}
\hline PARAMETERS & SYSTEM & $\begin{array}{c}\text { BOOST } \\
\text { CONVERTER } \\
\text { OUTPUT } \\
\text { WITHOUT MPPT } \\
\text { CONTROLLER }\end{array}$ & $\begin{array}{c}\text { BOOST } \\
\text { CONVERTER } \\
\text { OUTPUT WITH } \\
\text { MPPT } \\
\text { CONTROLLER }\end{array}$ \\
\hline VOLTAGE & \multirow{3}{*}{ SOLAR SYSTEM } & 165.87 & 132.87 \\
\hline CURRENT & & 0.672 & 1.13 \\
\hline POWER & & 110.55 & 150.14 \\
\hline VOLTAGE & \multirow{3}{*}{ WIND SYSTEM } & 730 & 627 \\
\hline CURRENT & & 1.82 & 2.508 \\
\hline POWER & & 1330 & 1572.5 \\
\hline
\end{tabular}

\section{v. CONCLUSION}

In this paper maximum power point was tracked in both solar and wind energy conversion systems. Modelling of photovoltaic module was done under different temperature and different solar radiation conditions. The wind system include wind turbine, permanent magnet synchronous generator, etc. The wind power generation depends on wind speed, velocity and fluctuating of weather conditions. Maximum power point of operation was tracked for both the systems Incremental Conductance algorithm used for Solar system and Perturb and Observe algorithm used for Wind energy conversion system. The performance of solar system and wind system are analyzed and comparing the with MPPT results and without MPPT results. The MPPT controller gives the best results in both the systems. The MPPT controller was effectively track the maximum power from the solar and wind energy sources. Which increase the efficiency of the hybrid system.

\section{REFERENCES}

[1] Ravi Prakash and Sandeep singh,"Designing and modelling of solar photovoltaic cell and array" IOSR journal of electrical and electronics engineering, vol.11, issue 2, April 2016.

[2] Kajal shah, Vishal Gaur, Siddharth Joshi, Nitin Patel, "Maximum power point tracking methods for wind and solar conversion systems for standalone generation PSIM based perturb and Observe Method" International Journal of Engineering Research and Development, April 2015.

[3] T.Salmi,M.Bouzguenda,A.Gagtli,"MATLAB/Simulik based modelling of solar photovoltaic cell" International Journal of Renewable Energy Research, vol.2, issue2, 2012.

[4] Deepthi Nightingale Pullagura, G. Madhusudhana Rao, P. Jaya Babu,"MPPT Control of solar and wind Energy of a Standalone Hybrid Power Generation System", International journal of scientific Engineering and Research, Nov 2016.
[5] Kivanc Basaran, Numan Sabit Cetin,"Energy Management for on-grid and off-grid Wind/PV and battery hybrid system", IET Renewable Power Generation,2017.

[6] Saravanan, Babu NR, "Maximum Power point tracking algorithms for photovoltaic system-A Review", International Renewable and sustainable energy conference, 2016.

[7] Kamal Anoune, Abdelali Aatito, "Hybrid Renewable Energy System to Maximize the Electrical Power Production", International Renewable and sustainable energy conference, Nov 2016.
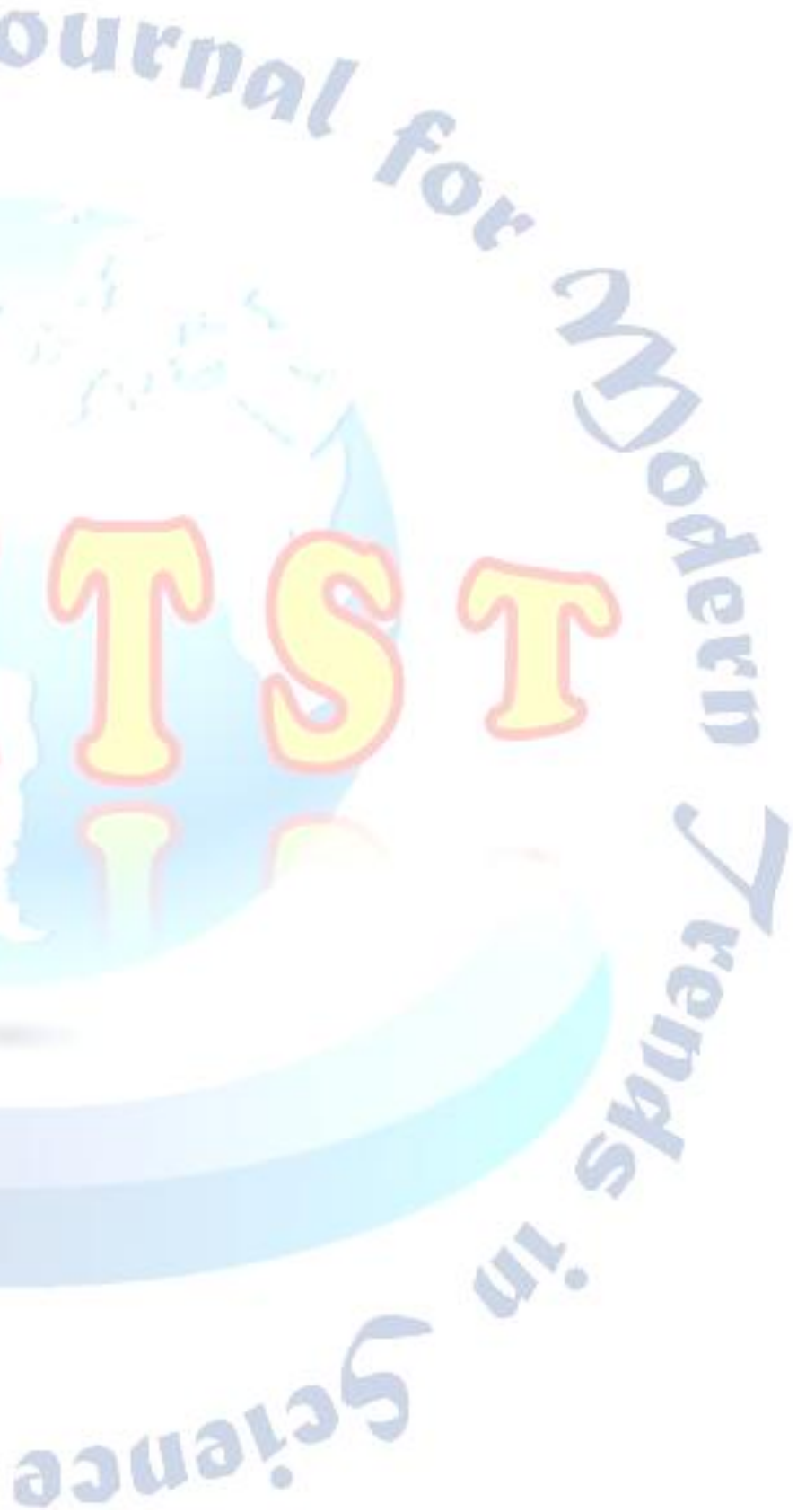